\title{
Isolation, Characterization and Pathogenicity of the Most Common Bacteria Associated with Gut Health in Egyptian Broiler Chicken Flocks
}

\author{
Ali Z. Qandoos ${ }^{1}$, Nayera M. Alatfeehy ${ }^{2}$ and Wafaa A. Abd El-Ghany ${ }^{1 *}$ \\ ${ }^{1}$ Poultry Diseases Department, Faculty of Veterinary Medicine, Cairo University, 12211, Giza, Egypt \\ ${ }^{2}$ Research Laboratory for Veterinary Quality Control, Animal Health Research Institute, Egypt \\ *Corresponding author: wafaa.soliman1974@gmail.com
}

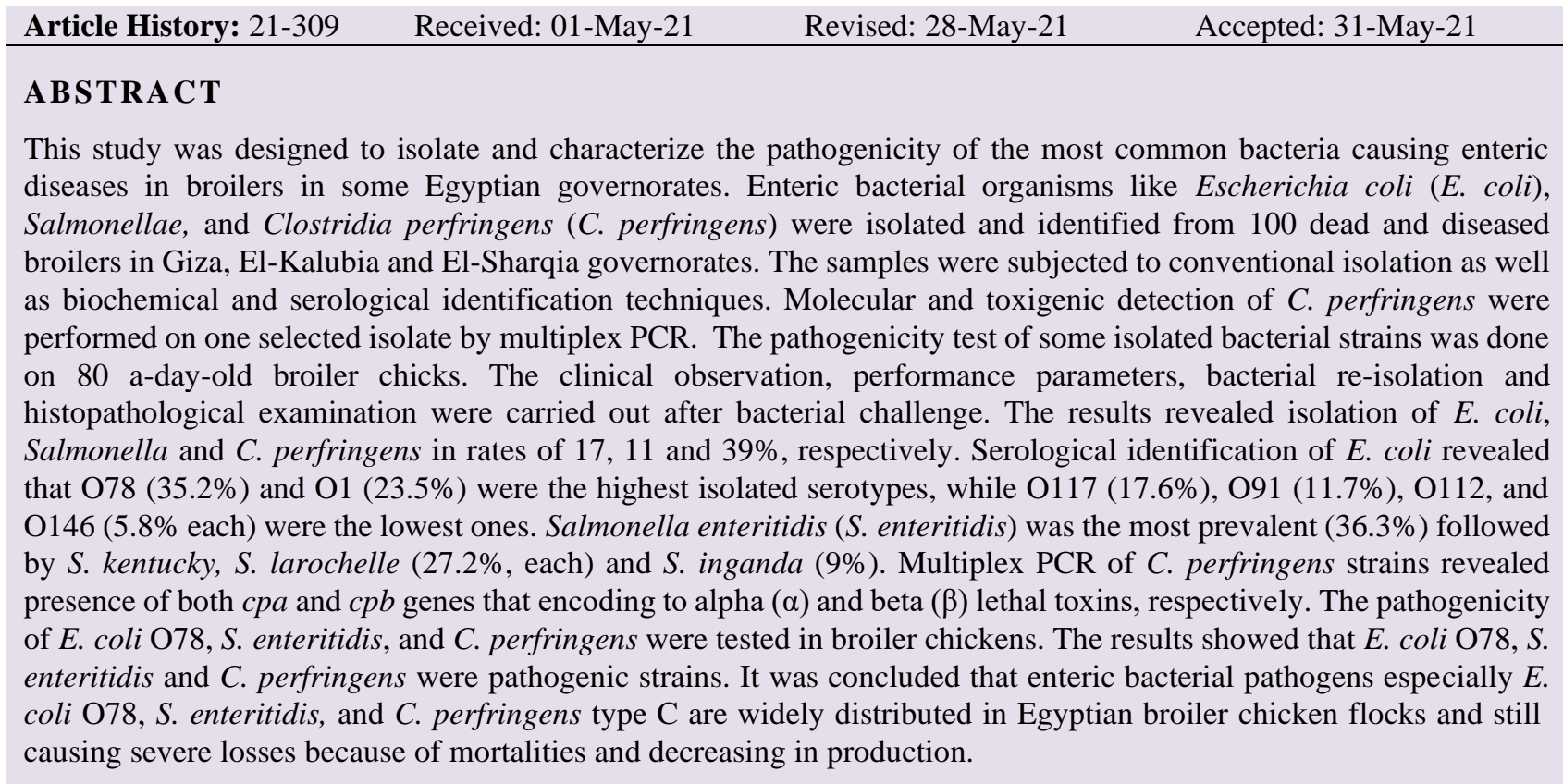

Key words: E. coli; Clostridium; Broiler; Egypt; Salmonella.

\section{INTRODUCTION}

Animal production especially poultry sector represents as a major source of high-quality human's food worldwide. This sector is subjected for infectious and non-infectious constrains that adversely affect the productivity. Enteric infection is regarded as one of the most important problem that causes severe damage of the digestive tract of poultry (Reynolds 2003). Poor feed efficiency parameters as well as high mortalities of birds resulting from intestinal damage due to bacterial enteric infections (Awaad et al. 2019). Enteric diseases like salmonellosis, colibacillosis, and Clostridial infection have a significant and adverse impact on poultry industry as a result of severe worldwide economic losses. These losses include poor growth performance, increased mortality, zoonotic significance as well as increased medication costs (Hussein et al. 2013; Soliman et al. 2018).

Avian colibacillosis caused by Escherichia coli (E. coli) is one of the main widespread bacterial infection that causes losses and a decrease in the production (Ronco et al. 2017; Ellakany et al. 2019; Mehmood et al. 2020). Some strains of $E$. coli are presented as intestinal commensal of birds, but in weak immune hosts, the pathogenic or even non-pathogenic strains can cause diseases conditions (Sarba et al. 2019). Infection with E. coli in poultry may induce acute septicemia with high mortality or appear in subacute form with polyserositis (Calnek et al. 1997). The most prevalent serogroups of pathogenic E. coli in chickens are belonging to $\mathrm{O} 78, \mathrm{O} 1$, and $\mathrm{O} 2$, and to a lesser extent, O15 and O55 (Rahman et al. 2004; Ali et al. 2019).

Cite This Article as: Qandoos AZ, Alatfeehy NM and Abd El-Ghany WA, 2022. Isolation, characterization and pathogenicity of the most common bacteria associated with gut health in Egyptian broiler chicken flocks. International Journal of Veterinary Science 11(1): 7-15. https://doi.org/10.47278/journal.ijvs/2021.069 
Salmonellosis caused by paratyphoid Salmonella species, is one of the major worldwide foodborne pathogens that transmit to human through consumption of raw or insufficient prepared poultry meat. In addition to the significant public health problem, paratyphoid Salmonella species have adverse economic impact on poultry industry that represented by high mortality and morbidity, and impaired production (Shoaib et al. 2017; Alam et al. 2020). Multiple Salmonella serotypes induce different diseases conditions in nearly all types of avian species ( $\mathrm{Su}$ et al. 2011). However, Salmonella enteritidis (S. enteritidis) is regarded as the most dominating serovar that affecting poultry flocks (Schlundt 2002; Afshari et al. 2018; Yasmin et al. 2020; Ahmad et al. 2020).

Necrotic enteritis is an important disease condition that is characterized by high mortality, poor feed conversion, weight losses as well as decreasing in egg production of the affected birds (Sarkar et al. 2013; la Mora et al. 2020). Coccidial affection is the main predisposing factor for initiation of necrotic enteritis (Palliyeguru et al. 2010). The disease in poultry is regards as enterotoxaemia caused by Clostridium perfringens (C. perfringens) (Williams 2005). Based on the production of major lethal toxins $\alpha, \beta, \varepsilon$ and iota (i). Clostridium perfringens can be classified into five toxin production biotypes (A, B, C, D, and E) (Uzal et al. 2014). Types A and $C$ of $C$. perfringens are the most important types that affecting poultry. However, $C$. perfringens type $\mathrm{A}$ is regarded as the most common type and to a lesser extend type C. Strains of $C$. perfringens type A have gene coding $\alpha$-toxin ( $c p a)$, while type $C$ have both $\alpha$-toxin (cpa) and $\beta$-toxin (cpb) gene encoding (Enstrom et al. 2003; Abd El-Hamid et al. 2015). Accordingly, this work was designed to isolate, characterize, and detect the pathogenicity of the most common bacteria causing enteric diseases in broiler chickens in some Egyptian governorates.

\section{MATERIALS AND METHODS}

The pathogenicity test was carried out after the approval of the Institutional Animal Care and Use Committee, Cairo University (CU-IACUC) (CU II F 320 ).

\section{Samples Collection}

This research work was conducted during the period from April till September 2019. A total of 100, 4-6-weeksold diseased and freshly dead broilers with a history of diarrhea, depression, and reduced growth performance were collected from different flocks in Giza, El-Kalubia, and El-Sharkia governorates of Egypt. The examined dead birds showed severe enteritis, general congestion of the internal abdominal viscera as well as perihepatitis, pericarditis and peritonitis. Samples including heart, liver, and intestine were collected, identified, and rapidly transported to the laboratory in an icebox for further processing.

\section{Isolation and Characterization of the Enteric Bacterial Strains}

Isolation of $E$. coli was done according to Lee and Nolan (2008). Collected samples were cultured on tryptic soy broth and incubated at $37^{\circ} \mathrm{C}$ for 18 hours. A loop full of incubated broth was streaked into MacConkey's agar and incubated at $37^{\circ} \mathrm{C}$ for $18-24$ hours. The suspected $E$. coli colonies were subjected for morphological and biochemical identification. The isolates were serologically identified as Kok et al. (1996) by using rapid diagnostic $E$. coli antisera sets (Denka Seiken Co, Japan).

Besides, isolation and identification of Salmonella species were done according to standard methods (ISO 6579 2002). Rappaport-Vassiliadis enrichment broth was used for isolation of Salmonella and incubated at $37^{\circ} \mathrm{C}$ for 18 hours. A loop-full of culture was streaked into Xylose Dextrose (XLD) and MacConkey agar and incubated at $37^{\circ} \mathrm{C}$ for $18-24$ hours. The morphological and bio-chemical identification were carried out on the suspected colonies, while the serotyping was done as described by Kauffmanwhite scheme (Kauffman 1974; Popoff 2001) for somatic (O) and flagella $(\mathrm{H})$ antigens using Salmonella antiserum (DENKA SEIKEN Co. Japan).

For Clostridia isolation, the samples were inoculated into a cooked meat broth medium and incubated in an anaerobic gas pack jar for 24 hours at $37^{\circ} \mathrm{C}$. A loop full of broth culture was streaked onto $10 \%$ sheep blood agar, supplemented with neomycin sulfate $(200 \mu \mathrm{g} / \mathrm{ml})($ Carter and Cole 1990) and incubated anaerobically at $37^{\circ} \mathrm{C}$ for 24 hours. Gram staining from suspected colonies were prepared for microscopical examination. Biochemical identification was applied (Koneman et al. 1988). The strains were maintained in $25 \%$ glycerol stock at $-80^{\circ} \mathrm{C}$ until further use.

\section{Detection of Clostridium perfringens Toxins using Multiplex PCR}

Genomic DNA was extracted from $C$. perfringens strain by culturing on blood agar media using QIAamp Mini Kit (Cat No. 51304). The specific three primer sets design corresponding to each $\alpha, \beta$ and $\varepsilon$ toxins of $C$. perfringens (Komoriya et al. 2007; van Asten et al. 2009) is shown in Table 1. The PCR was performed in a Thermal Cycler $^{\circledR}$ (Bio-Rad, USA) in a total reaction volume of 50M containing $25 \mathrm{M}$ of $2 \mathrm{x}$ Master Mix (thermos scientific, $1 \mathrm{M}$ of $1 \mathrm{pmol}$ of each primer and $5 \mathrm{M}$ of template DNA). Cycling conditions of the primers during multiplex PCR is represented in Table 2 . Then, $8 \mathrm{M}$ of the amplified product was electrophoresed in a $1.5 \%$ agarose gel and stained with ethidium bromide. Amplified bands were visualized and photographed under ultraviolet illumination.

Table 1: Primers used in multiplex PCR for the detection of toxin's type of C.perfringens

\begin{tabular}{lllll}
\hline Amplicon $(\mathrm{bp})$ & Primer position & Sequence & Gene & Toxin \\
\hline 324 & $663-968$ & GCTAATGTTACTGCCGTTGA & $\alpha$ \\
& & CCTCTGATACATCGTGTAAG & & \\
196 & $871-1045$ & GCGAATATGCTGAATCATCTA & cpb & $\beta$ \\
655 & $267-862$ & GCAGGAACATTAGTATATCTTC & etx & $\varepsilon$ \\
\hline
\end{tabular}




\section{The Pathogenicity Test}

Eighty, day-old chicks obtained from local hatchery were divided into 4 equal groups consisting of 20 birds each. Each group was housed in a thoroughly cleaned and disinfectant pen, given feed and water ad libitum as well as vaccination programs according to the manufacturer's instructions. Group 1 was a negative control nonchallenged birds, while groups 2,3 , and 4 were challenged orally at 2 weeks of age. Each bird of the challenged groups was inoculated with $1 \mathrm{ml}$ containing $1 \times 10^{8}$ Colony Forming Unit (CFU) for $C$. perfringens type $\mathrm{C}$ and $1 \times 10^{9}$ for $S$. enteritidis and E. coli $\mathrm{O} 78$ (Barrow et al. 1999; Botlhoko 2009; Johny et al. 2012; Abd El-Tawab et al. 2015b). Chickens in C. perfringens challenged group were orally inoculated with a mixture of Eimeria species oocysts $(0.25 \mathrm{ml} / \mathrm{bird})$ at 12 days old to stimulate necrotic enteritis induction (Williams et al. 2003). The body weight and feed consumption of each group were taken weekly to measure the feed conversion ratio (FCR). Moreover, clinical signs, mortality rates, and post-mortem lesions of chickens in the challenged groups were recorded every day for 3 weeks later. Specimens including heart, liver, and intestine were collected from dead and euthanized birds (at the $3^{\text {rd }}$ week post-challenge) for bacterial re-isolation and histopathological examination.

\section{The Histopathological Examination}

Specimens including liver, intestine and heart were collected and fixed in $10 \%$ formalin solution, dehydrated in different grades of ethyl alcohol, and embedded in paraffin. Tissues of 5 microns thickness were stained with hematoxylin and Eosin (H\&E) and microscopically examined using light microscope (Slaoui and Fiette 2011).

\section{Statistical Analysis}

Data were expressed as mean \pm SE. Statistical comparison between the mean of the different groups was made by One-Way Analysis of Variance (ANOVA) and multiple comparisons between groups (post hoc) LSD using SPSS version 26. A probability $\mathrm{P} \leq 0.05$ was assumed for statistical significance.

\section{RESULTS}

The results of isolation of some enteric bacterial strains in different Egyptian governorates are illustrated in Table 3. From the table, it could be observed that the isolation rate of $E$. coli from 17 out of 100 samples was $17 \%$. Culturing of suspected E. coli samples on MacConkey's agar showed medium-sized, rounded, and pink colonies. Gram's staining revealed Gram-negative, non-sporulated bacilli that arranged single, pairs, and in groups. In addition, the biochemical tests of the suspected isolates showed negative oxidase, urease, citrate utilization, and Voges Proskauer tests, but positive catalase, indole, methyl red, nitrate reduction and triple sugar iron tests. The isolates showed motility in semisolid agar media. The serological identification of the suspected $E$. coli isolates in different Egyptian governorates is shown in Table 4. The results demonstrated that the most predominant serotypes were $\mathrm{O} 78$ (6 isolates) followed by $\mathrm{O} 1$ (4 isolates), O117 (3 isolates), O91 (2 isolates), and O112, O146 (one isolate; each).

Regarding the isolation of Salmonellae, the isolation rate of Salmonellae was $11 \%$ as 11 out 100 samples were positive (Table 3). Colonies of suspected Salmonellae cultures appeared as pink with black center on XLD agar and colorless ones on MacConkey agar, while Gramnegative medium size bacilli were seen in stained culture smears. Biochemical identification of cultures showed positive catalase, methyl red, citrate utilization, $\mathrm{H}_{2} \mathrm{~S}$ production tests, while negative oxidase, indole, urease, Voges Proskauer, and gelatin liquefaction tests. Sugar fermentation was positive for glucose, maltose, and xylose, whereas negative for lactose and sucrose. Serological identification of the suspected Salmonella isolates in different Egyptian governorates was $S$. enteritidis (4), $S$. kentucky (3), S. larochelle (3), and S. inganda (1) as represented in Table 5.

Table 2: Cycling conditions of the primers during multiplex PCR for the detection of toxin's type of C. perfringens

\begin{tabular}{llllcl}
\hline $\begin{array}{l}\text { Primary } \\
\text { Denaturation }\end{array}$ & Secondary & Annealing & \multirow{2}{*}{ Extension } & No. of cycles & Final \\
Extension
\end{tabular}

Table 3: The isolation rate of enteric bacterial strains in different Egyptian governorates

\begin{tabular}{|c|c|c|c|c|c|c|c|c|}
\hline \multirow{3}{*}{$\begin{array}{l}\text { The } \\
\text { governorate }\end{array}$} & \multirow{3}{*}{$\begin{array}{c}\text { Status of } \\
\text { examined } \\
\text { birds }\end{array}$} & \multirow{3}{*}{$\begin{array}{l}\text { No. of } \\
\text { samples }\end{array}$} & \multicolumn{6}{|c|}{ The isolated enteric bacterial isolates } \\
\hline & & & \multicolumn{2}{|c|}{ E. coli } & \multicolumn{2}{|c|}{ Salmonella } & \multicolumn{2}{|c|}{ Clostridia } \\
\hline & & & $\begin{array}{l}\text { No. of } \\
\text { positive } \\
\text { samples }\end{array}$ & $\begin{array}{c}\% \text { of positive } \\
\text { samples }\end{array}$ & $\begin{array}{l}\text { No. of } \\
\text { positive } \\
\text { samples }\end{array}$ & $\begin{array}{c}\% \text { of } \\
\text { positive } \\
\text { samples }\end{array}$ & $\begin{array}{l}\text { No. of } \\
\text { positive } \\
\text { samples }\end{array}$ & $\begin{array}{c}\% \text { of } \\
\text { positive } \\
\text { samples }\end{array}$ \\
\hline \multirow{3}{*}{ Giza } & Diseased & 20 & 2 & $10^{*}$ & 1 & $5^{*}$ & 5 & $25^{*}$ \\
\hline & Dead & 6 & 1 & $16.7^{*}$ & 1 & $16.7^{*}$ & 2 & $33.3^{*}$ \\
\hline & Total & 26 & 3 & $11.5^{* *}$ & 2 & $33.3^{* *}$ & 7 & $26.9^{* *}$ \\
\hline \multirow{3}{*}{ El-Kalubia } & Diseased & 35 & 5 & $14.3^{*}$ & 4 & $11.4^{*}$ & 18 & $51.4^{*}$ \\
\hline & Dead & 8 & 3 & $37.5^{*}$ & 2 & $25^{*}$ & 3 & $37.5^{*}$ \\
\hline & Total & 43 & 8 & $18.6^{* *}$ & 6 & $14^{* *}$ & 21 & $48.8^{* *}$ \\
\hline \multirow{3}{*}{ El-Sharqia } & Diseased & 25 & 4 & $16^{*}$ & 0 & 0 & 9 & $36^{*}$ \\
\hline & Dead & 6 & 2 & $33.3^{*}$ & 3 & $50^{*}$ & 2 & $33.3^{*}$ \\
\hline & Total & 31 & 6 & $19.9^{* *}$ & 3 & $9.7^{* *}$ & 11 & $35.5^{* *}$ \\
\hline Total & & 100 & 17 & $17^{* * * *}$ & 11 & $11^{* * * *}$ & 39 & $39^{* * * *}$ \\
\hline
\end{tabular}

*The percentage was calculated according to each bird's status; ${ }^{* *}$ The percentage according to the total number in each governorate

****The percent according to the total number of tested samples. 


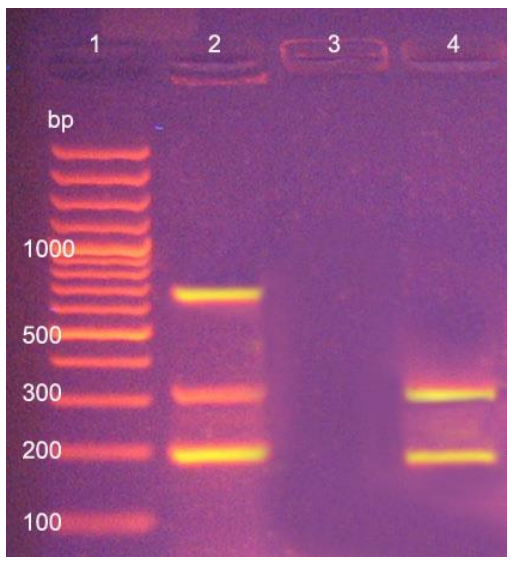

Fig. 1: Agarose gel (1.5\%) electrophoresis of multiplex PCR products of $C$. perfringens toxins; Lane 1: DNA marker (Gene Ruler 100 bp DNA Ladder, Thermo-scientific); Lane 2: Control Positive (mix of various toxin types); Lane 3: Control negative and Lane 4: PCR product of the isolate toxin.

Table 4: The serological identification of $E$. coli isolates in different Egyptian governorates

\begin{tabular}{llcc}
\hline $\begin{array}{l}\text { The } \\
\text { governorate }\end{array}$ & $\begin{array}{l}\text { Total No. of } \\
\text { isolated } E . \\
\text { coli }\end{array}$ & Serogroup & $\begin{array}{c}\text { No. of each } \\
\text { serotype }\end{array}$ \\
\hline Giza & 3 & O78 & 1 \\
& & O146 & 1 \\
& O91 & 1 \\
\hline El-Kalubia & 8 & O78 & 3 \\
& & O1 & 3 \\
& & O91 & 1 \\
\hline El-Sharkia & 6 & O112 & 1 \\
& & O117 & 3 \\
& & O78 & 2 \\
\hline Total & O1 & 1 \\
\hline
\end{tabular}

Table 5: The serological identification of Salmonella isolates in different Egyptian governorates

\begin{tabular}{lllc}
\hline $\begin{array}{l}\text { The } \\
\text { governorate }\end{array}$ & $\begin{array}{c}\text { Total No. } \\
\text { of isolates }\end{array}$ & Serotypes & $\begin{array}{c}\text { No. of each } \\
\text { serotype }\end{array}$ \\
\hline Giza & 2 & $\begin{array}{l}\text { S. kentucky } \\
\text { S. inganda }\end{array}$ & 1 \\
& & S. kentucky & 1 \\
\hline El-Kalubia & 6 & S. enteritidis & 2 \\
& & S. larochelle & 2 \\
\hline El-Sharkia & 3 & S. enteritidis & 2 \\
& & S. larochelle & 1 \\
\hline Total & \multicolumn{3}{c}{11}
\end{tabular}

The results of $C$. perfringens isolation rate that presented in Table 3 demonstrated that out of 100 examined samples, 39 (39\%) were positive. Anaerobic incubation of suspected samples on sheep blood agar showed presence of small, circular, smooth, flat, glistening and greyish colonies surrounded by double zones of hemolysis. Microscopically, Gram-positive spore-forming bacilli were noticed. Biochemically, positive results for lecithinase activity on yolk agar as well as sugar fermentation of glucose, lactose, maltose, and sucrose were demonstrated. Nevertheless, negative results for indole production, catalase, and oxidase were also found. The results of multiplex PCR for detection of the toxin types for $C$. perfringens revealed presence of the gene coding $\alpha$ toxin (cpa) and the gene encoding $\beta$ toxin (cpb) (Fig. 1). The latter results indicated presence of $C$. perfringens type $\mathrm{C}$.
Regarding the pathogenicity test, the mortality rate and the post-mortem lesions in different challenged groups are seen in Table 6 . No clinical signs were appeared in negative control non-challenged birds, but birds challenged with $E$. coli $\mathrm{O} 78$ showed depression, brownish diarrhea, nasal and ocular discharge and conjunctivitis. Greenish diarrhea and poor growth were seen in chickens challenged with $S$. enteritidis, while bloody diarrhea, and ruffled feather were noticed in birds challenged with $C$. perfringens. Control negative non challenged birds showed no mortalities while chickens challenged with $E$. coli $\mathrm{O} 78, S$. enteritidis, and $C$. perfringens revealed mortality rates of 25,15 and $35 \%$, respectively. The necropsy findings of dead and sacrificed bird's revealed perihepatitis, pericarditis and enteritis in group challenged with $E$. coli $\mathrm{O} 78$; enlarged liver with necrotic foci, perihepatitis, enlarged congested kidney and enteritis in group challenged with $S$. enteritidis, as well as friable ballooned intestine with hemorrhagic mucosa and necrotic pale liver in group $C$. perfringens.

Table 7 shows the average body weight and FCR in different groups. In comparison with control negative nonchallenged group, challenged groups revealed significant decrease in body weight and feed consumption with $\mathrm{P} \leq 0.05$ that reflected on the FCR.

The re-isolation rates of bacteria from different organs in different challenged groups are present in Table 8. The re-isolation rates of E. coli, Salmonella, and Clostridia from visceral organs were 85, 70, and $85 \%$ in birds challenged with $E$. coli $\mathrm{O} 78, S$. enteritidis and $C$. perfringens, respectively. In a group challenged with $E$. coli $\mathrm{O} 78$, the highest incidence of re-isolation was from heart $(88.2 \%)$, then from liver $(76.4 \%)$ and intestine $(70.5 \%)$. For chickens challenged with $S$. enteritidis, the highest re-isolation was from liver $(92.8 \%)$, intestine $(85.7 \%)$ followed by heart $(64.2 \%)$, while in birds challenged with $C$. perfringens, this rate was $88.2 \%$ from the intestine and $70.5 \%$ from the liver.

Fig. 2 to 4 show the histopathological examination results in the challenged groups of birds. The different lesions in the liver, intestine and heart of group challenged with E. coli $\mathrm{O} 78$ are demonstrated (Fig. 2A to 2D). Chickens exhibited diffuse hepatocellular necrosis which was characterized by numerous sporadic cell necrosis among the hepatocytes admixed with accumulation of diffuse edema, eosinophilic debris, and a variable number of mononuclear inflammatory cells infiltration. The intestine showed severe necrosis of the intestinal villi associated with intense inflammatory cells infiltration. The myocardial muscle revealed diffuse myocarditis which was illustrated by extensive number of mononuclear inflammatory cells infiltration.

Fig. $3 \mathrm{~A}$ to $3 \mathrm{D}$ show the hepatic and intestinal microscopic alterations of $S$. enteritidis challenged chickens. The hepatic parenchyma showed multifocal edematous areas accompanied by dilation of the hepatic sinusoids. Numerous clusters of basophilic septicemic bacteria were detected in the hepatic sinusoids. The hepatocytes suffered from widespread coagulative necrosis. The intestinal sections showed severe necrosis which is characterized by atrophy of intestinal villi associated with accumulation of eosinophilic and karyorrhectic debris. 
Int J Vet Sci, 2022, 11(1): 7-15.

Table 6: The mortality rates and post-mortem lesions in different challenged groups

\begin{tabular}{llcl}
$\begin{array}{l}\text { Group } \\
\text { No. }\end{array}$ & $\begin{array}{l}\text { Challenge } \\
\text { bacteria }\end{array}$ & $\begin{array}{c}\text { The mortality } \\
\text { rate }\end{array}$ & Post-mortem lesions \\
\hline 1 & - & $0(0)$ & - \\
2 & E. coli $(\mathrm{O} 78)$ & $5(25)$ & Perihepatitis, pericarditis and enteritis \\
3 & S. enteritidis & $3(15)$ & Enlarged liver with necrotic foci, perihepatitis, enlarged congested kidney and enteritis \\
4 & C. perfringens & $7(35)$ & friable ballooned intestine with hemorrhagic mucosa and necrotic pale liver \\
\hline
\end{tabular}

Values in parenthesis indicate percentage.

Table 7: The average body weight (g/bird) and the FCR in different groups

\begin{tabular}{|c|c|c|c|c|c|c|c|}
\hline \multirow{3}{*}{$\begin{array}{l}\text { Group } \\
\text { No. }\end{array}$} & \multirow{3}{*}{$\begin{array}{l}\text { Challenge } \\
\text { bacteria }\end{array}$} & \multicolumn{5}{|c|}{ Average body weight (g/bird) } & \multirow[t]{3}{*}{ FCR } \\
\hline & & \multicolumn{2}{|c|}{ Weeks before infection } & \multicolumn{3}{|c|}{ Weeks after infection } & \\
\hline & & W1 & W2 & W3 & W4 & W5 & \\
\hline 1 & - & $160.7 \pm 3.1^{\mathrm{a}}$ & $422.2 \pm 10.0^{\mathrm{a}}$ & $853.0 \pm 19.3^{\mathrm{a}}$ & $1347.0 \pm 9.7 \mathrm{a}$ & $1898.0 \pm 26.0 \mathrm{a}$ & $1.673^{\mathrm{a}}$ \\
\hline 2 & E. coli $(\mathrm{O} 78)$ & $161.0 \pm 4.6^{\mathrm{a}}$ & $430.7 \pm 10.9^{a}$ & $762.1 \pm 12.6^{\mathrm{b}}$ & $1223.8 \pm 15.0^{\mathrm{b}}$ & $1681.2 \pm 15.5^{b}$ & $1.794^{\mathrm{b}}$ \\
\hline 3 & S. enteritidis & $155.2 \pm 4.0^{\mathrm{a}}$ & $432.0 \pm 10.4^{\mathrm{a}}$ & $777.1 \pm 17.9^{b}$ & $1223.6 \pm 14.1^{b}$ & $1682.5 \pm 14.4^{b}$ & $1.777^{\mathrm{b}}$ \\
\hline 4 & C. perfringens & $163.25 \pm 4.4^{\mathrm{a}}$ & $425.2 \pm 10.0^{\mathrm{a}}$ & $757.5 \pm 16.8^{b}$ & $1212.3 \pm 18.8^{b}$ & $1676.0 \pm 20.8^{b}$ & $1.789^{\mathrm{b}}$ \\
\hline
\end{tabular}

$\mathrm{W}=$ Week; FCR=Feed conversion ratio. Mean \pm SE in the same column followed by the different superscripts is significantly different according to ANOVA (LSD, $\mathrm{P} \leq 0.05$ ).

Table 8: The re-isolation rates of bacteria from different organs in different challenged groups

\begin{tabular}{llcccc}
\hline Group No. & Challenge bacteria & The total re- & \multicolumn{2}{c}{ The re-isolation rate from different organs } \\
\cline { 4 - 6 } & & isolation rate & Liver & Heart & Intestine \\
\hline 1 & - & $0(0)$ & $0(0)$ & $0(0)$ & $0(0)$ \\
2 & E. coli $(\mathrm{O} 78)$ & $17 / 20(85)$ & $13 / 17(76.4)$ & $15 / 17(88.2)$ & $12 / 17(70.5)$ \\
3 & S. enteritidis & $14 / 20(70)$ & $13 / 14(92.8)$ & $9 / 14(64.2)$ & $12 / 14(85.7)$ \\
4 & C. perfringens & $17 / 20(85)$ & $12 / 17(70.5)$ & $0 / 14(0)$ & $15 / 17(88.2)$ \\
\hline
\end{tabular}

Values in parenthesis indicate percentage.

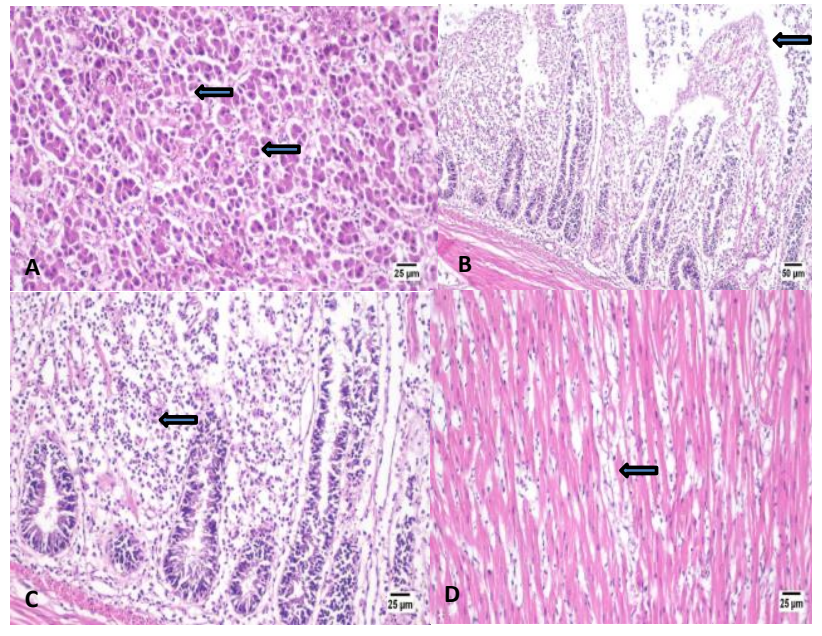

Fig. 2: A) Liver of $E$. coli challenged group showing sporadic cell necrosis (arrows); B) Intestine of E. coli challenged group showing severe necrosis of the intestinal villi (arrow); C) Intestine of E. coli challenged group showing intestinal necrosis admixed with accumulation of inflammatory cells and tissue debris in the submucosa (arrow) and Heart of E. coli challenged group showing myocarditis (arrow). $\mathrm{H} \& \mathrm{E}$. Bar $=25 \mu \mathrm{m}$ (A, B and D); $50 \mu \mathrm{m}(\mathrm{C})$.

In $C$. perfringens challenged group, variable lesions have been noticed in the liver and intestine (Fig. 4A to 4D). The liver showed multifocal to diffuse hemorrhagic areas accompanied by disorganization of the hepatic parenchyma. The hepatocytes showed marked necrobiotic changes that showed vacuolation and several stages of nuclear necrosis that including karyorrhexis, karyolysis, and pyknosis. The intestine revealed marked atrophy of the intestinal villi accompanied by enteritis that showed expansion of the submucosal layer with edema and mononuclear inflammatory cells infiltration.

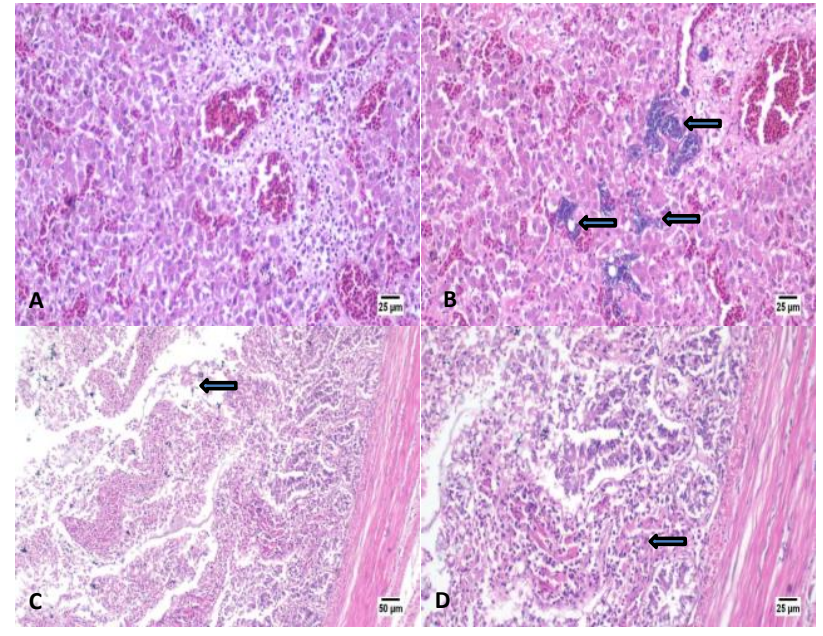

Fig. 3: A) Liver of $S$. enteritidis challenged group showing congested hepatic sinusoids, edema and few inflammatory cells infiltration; B) Liver of $S$. enteritidis challenged group showing multifocal aggregation of bacterial colonies (arrows); C) Intestine of $S$. Enteritidis challenged group showing severe necrosis of the intestinal villi, crypts and intestinal glands (arrow) and D) Intestine of $S$. enteritidis challenged group showing severe necrosis of the intestinal glands admixed with mononuclear inflammatory cells infiltration in the submucosa (arrow). H\&E. $\mathrm{Bar}=25 \mu \mathrm{m}(\mathrm{A}, \mathrm{B}$ and D); $50 \mu \mathrm{m}(\mathrm{C})$.

\section{DISCUSSION}

Enteric bacterial diseases are regarded as one of the most important group of diseases that affect broiler chickens and causes severe economic losses in poultry production (Hafez 2011; Abdel-Alim and Ahmed 2020) Therefore, this study is focused on isolation and characterization of some important enteric bacteria in different Egyptian governorates. 


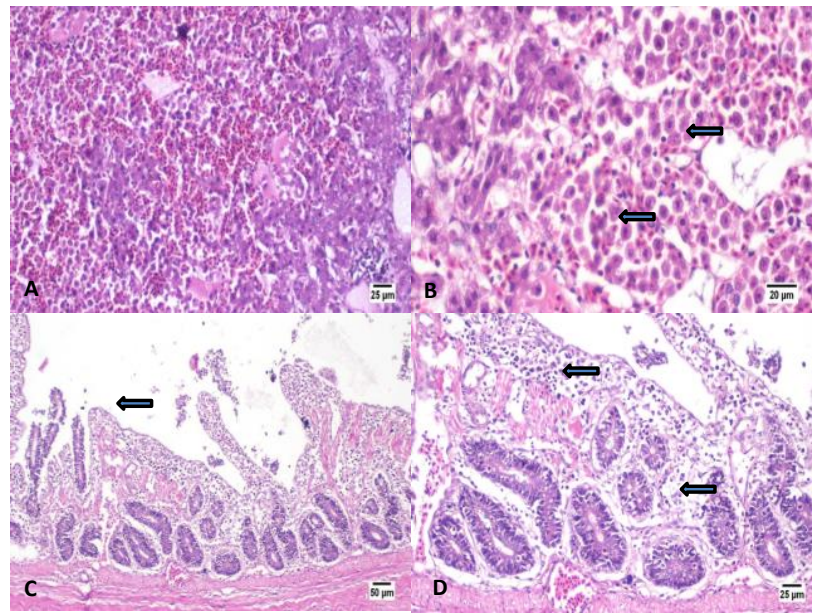

Fig. 4: A) Liver of $C$. perfringens challenged group showing hepatic hemorrhages; B) Liver of $C$. perfringens challenged group showing several stages of nuclear necrosis in the affected hepatocytes (arrows); C) Intestine of $C$. perfringens challenged group showing marked atrophy and shortening of the intestinal villi (arrow) and D) Intestine of $C$. perfringens challenged group showing expansion of the submucosa with edema and mononuclear inflammatory cell accumulation (arrows). H\&E. Bar $=25 \mu \mathrm{m}(\mathrm{A}, \mathrm{B}$ and D); $50 \mu \mathrm{m}(\mathrm{C})$.

Here, E. coli strains have been detected in 17 out of 100 samples with isolation rate of 17\%. Previous Egyptian studies on E. coli revealed either higher isolation rates $75 \%$ (Abd El-Tawab et al. 2015a), 43.1\% (Heba et al. 2012), 35\% (Amer et al. 2018), 34.6\% (Ellakany et al. 2019) and 27.7\% (Abd El-Mongy et al. 2017), while other showed lower isolation rate $8.3 \%$ (Ahmed et al. 2017). These differences in the isolation rates may be owing to the differences in the number of samples, the age of birds, the geographic regions, the isolation methods, and previous medication. The cultural morphology, Gram staining characters and biochemical reactions of suspected $E$. coli isolates were similar to those reported by Hadiujjaman et al. (2016), Surra et al. (2018) and Ibrahim et al. (2019). Moreover, the serological identification results of this study revealed that the main serotypes of the isolated $E$. coli were $\mathrm{O} 78$ and $\mathrm{O} 1$. These findings are parallel to the studies of Rahman et al. (2004) and Ibrahim et al. (2019) who found that $E$. coli $\mathrm{O} 78, \mathrm{O} 1$, and $\mathrm{O} 2$ were the predominant serotypes of the pathogenic $E$. coli in chickens. Besides, the Egyptian study of Amer et al. (2018) declared that $25 \%$ of E. coli isolates were $\mathrm{O} 78$.

This study showed isolation of Salmonellae in percentage of $11(11 / 100)$. Similar isolation rates were previously reported by Kaoud et al. (2018) and Soliman et al. (2018) who isolated Salmonellae from the Egyptian broiler flocks in rates of $11.33 \%$ and $10.37 \%$, respectively, Moreover, in Seri Lanka, Jayaweera et al. (2020) demonstrated isolation of Salmonellae from broiler chickens in rate of $11.6 \%$. However, Egyptian studies of Sedeik et al. (2019) and El-Sheikh et al. (2019) showed isolation of Salmonellae from broiler chicks in rates of $7.5 \%$ and $16 \%$, respectively. Regarding the colonial morphology and biochemical tests results of Salmonella, parallel results were also described by Akeila et al. (2013), Islam et al. (2016), Al-Mamun et al. (2017) and Mridha et al. (2020). Moreover, the serological results of the isolated Salmonellae showed that $S$. enteritidis and S. kentucky were the most among the isolates. Similar findings were reported by Moawad et al. (2017), Al-Baqir et al. (2019) and Sedeik et al. (2019) who demonstrated that $S$. enteritidis and $S$. kentucky were the most highly prevalent strains that isolated from chicken farms in Egypt. In addition, Wang et al. (2020) demonstrated variations of Salmonella serotypes in chicken's flocks and found that $S$. enteritidis was the most common isolated strain.

In addition, $C$. perfringens was isolated in rate of $39 \%$. Nearly similar isolation rate of $C$. perfringens was recorded in the study of Osman et al. (2012) who found that out of 48 broiler chicken samples, $35.4 \%$ were $C$. perfringens. Moreover, Abd-Elall and Maysa (2014) and Helal et al. (2019) declared that the prevalence of $C$. perfringens in broilers was 38.7 and $38.3 \%$, respectively. However, higher isolation rates of $C$. perfringens $(75 \%)$ and $(77.4 \%)$ were observed in the studies of El-Jakee et al. (2013) and Abd El-Hamid et al. (2015), respectively. The phenotypic characterization findings of $C$. perfringens isolates were similar to others (Das et al. 2008; Malmarugan et al. 2012; Dar et al. 2017). The results of multiplex PCR of $C$. perfringens strains confirmed presence of the gene coding $\alpha$-toxin (cpa) and the gene encoding $\beta$-toxin (cpb). Although $C$. perfringens type $\mathrm{A}$ is the predominant worldwide biotype type that isolated from chickens (Hatakka and Pakkala 2003; Merati et al. 2017), this works proved isolation of $C$. perfringens type C. Few studies either worldwide or locally showed isolation of $C$. perfringens type $\mathrm{C}$ from broiler chickens (Afshari et al. 2015).

Challenged groups with $E$. coli $\mathrm{O} 78$, S. enteritidis, and $C$. perfringens should variable diarrhea, respiratory signs and poor growth rate along with mortality rates of 25,15 and $35 \%$, respectively. Autopsy findings showed polyserositis and enteritis, liver necrosis, congested kidney and enteritis, along with friable ballooned intestine with haemorrhagic mucosa and necrotic pale liver in groups challenged with $E$. coli 078, S. enteritidis, and $C$. perfringens, respectively. Similar post-mortem observations in different groups were observed by Cooper and Songer (2010), Belih et al. (2016) and El-Sawah et al. (2018).

It has been observed significant $(\mathrm{P} \leq 0.05)$ differences in the average body weight and FCR in the challenged groups when compared with non-challenged group. Our results agreed with Abd El-Tawab et al. (2015b) who demonstrated depressive effect of $E$. coli on the performance parameters of chickens, Belih et al. (2016) who found significant reduction in body weight of chicken after challenge with Salmonella, as well as Abd El-Hamid et al. (2017) who demonstrated decrease in body weight, feed consumption and FCR in $C$. perfringens challenged chickens.

Re-isolation rates of $85 \%, 70 \%$, and $85 \%$ have been recorded in chickens challenged with E. coli O78, S. enteritidis and $C$. perfringens, respectively. These results are in partial agreement with Atta et al. (2014), Abd ElTawab et al. (2015a) and Gast et al. (2013).

The histopathological findings of chicken's liver, intestine and heart in group challenged with E. coli $\mathrm{O} 78$ are supported by the results obtained by Abalaka et al. (2017) and Shah et al. (2019). However, the microscopic changes of the liver and intestine of $S$. enteritidis challenged 
chickens revealed similar results to Saha et al. (2012) and Muna et al. (2016). The microscopic findings of the intestine and liver of $C$. perfringens challenged group correspond with other authors (Abd El-Hamid et al. 2015; Park et al. 2015).

From the previous findings, it may be concluded that many Egyptian broiler chicken's flocks showed circulation of different types of enteric bacterial pathogens, particularly E. coli $\mathrm{O} 78$, S. enteritidis, and C. perfringens type $\mathrm{C}$. These organisms are responsible for problems in poultry flocks resulting from increased morbidity, mortality, loss of productivity and public health significance. Periodical surveillance studies should be conducted to detect the epidemiological situation of these infections in poultry flocks. In addition, application of biosecurity measure is essential to prevent and/or eliminate these pathogens.

\section{Author's Contribution}

Ali Z. Qandoos shared in the laboratory work, the experimental study and the collection of data, Nayera M. Alatfeehy shared in the laboratory work and experimental study and collection of data and Wafaa A. Abd El-Ghany designed the work, shared in the experimental study along with writing and submission of the manuscript. All authors approved the final version.

\section{Financial Support}

This study was conduct without any financial support from any agency.

\section{REFERENCES}

Abalaka SE, Sani NA, Idoko IS, Tenuche OZ, Oyelowo FO, Ejeh SA and Enem SI, 2017. Pathological changes associated with an outbreak of colibacillosis in a commercial broiler flock. Sokoto Journal of Veterinary Sciences 15: 95-102. https://doi.org/10.4314/sokjvs.v15i3. 14

Abd-Elall AM and Maysa AI, 2014. Toxin genotyping of Clostridium perfringens isolated from broiler and layer farms and their workers in Egypt. Revue de Medecine Veterinaire 165: 272-279.

Abd El-Hamid HS, Ellakany HF, Bechet AA, Elbestawy AR and Bedawy S, 2015. Pathogenicity and antibiotic sensitivity of Clostridium perfringens isolates from chickens in El-Behera governorate, Egypt. Life Science Journal 12: 174-182.

Abd El-Hamid HS, Ellakany HF, Rizk MS, Elbestawy R and Abdelfatah SL, 2017. Effect of combined Clostridium perfringens infection and aflatoxicosis in broiler chickens. Alexandria Journal of Veterinary Sciences 52: 15-27. https://doi.org/10.5455/ajvs.239626

Abd El-Mongy M, Abd-El-Monem GM, Moawad AA and Mohammed ABA, 2017. Serotyping and virulence genes detection in Escherichia coli isolated from broiler chickens. Journal of Biological Sciences 18: 46-50. https://doi.org/ 10.3923/jbs.2018.46.50

Abd El-Tawab AA, Ammar AM, Nasef SA and Reda RM. 2015a. Prevalence of $E$. coli in diseased chickens with its antibiogram pattern. Benha Veterinary Medical Journal 28: 224-230. https://doi.org/10.21608/bvmj.2015.32507

Abd El-Tawab AA, El-Komy AA, El-Ekhnawy KI and Talaie AT, 2015b. Effect of fosfomycin on E. coli O78 isolated from broiler chickens in-vitro and in-vivo. Benha Veterinary Medical Journal 28: 294-300.

Abdel-Alim GA and Ahmed KA, 2020. The effect of cephardine on clinicopathological pictures of experimental Salmonella
Enteritidis and E. coli infections in broiler chickens. International Journal of Veterinary Science 9: 78-83.

Afshari A, Baratpour A, Khanzade S and Jamshidi A, 2018. Salmonella enteritidis and Salmonella typhimurium identification in poultry carcasses. Iranian Journal of Microbiology 10: 4550.

Afshari A, Jamshidi A, Razmyar J and Rad M, 2015. Genotyping of Clostridium perfringens isolated from broiler meat in northeastern of Iran. Veterinary Research Forum 6: 279-284.

Ahmad Y, Zahra R, Ali MI, Riaz MH, Khan R, Khan K, Khan MT, Ali A and Zeb MT, 2020. Molecular screening of resistant and virulent genes in Salmonella enteritidis and Salmonella typhimurium from poultry in Khyber Pakhtunkhwa. Pakistan Veterinary Journal 40: 343-349. https://doi.org/10.29261/pakvetj/2020.044

Ahmed SAM, Ahmed IA, Osman N and El-Hamd DM, 2017. Problem of Escherichia coli infection in broilers in Qena province. Assiut Veterinary Medical Journal 63: 252-264.

Akeila MA, Ellakany HF, Sedeik ME and Behar HM, 2013. Characterization and plasmid profiling of Salmonella enteritidis isolated from broiler chickens. Alexandria Journal of Veterinary Sciences 39: 105-111.

Alam SB, Mahmud M, Akter R, Hasan M, Sobur A, Nazir KNH, Noreddin A, Rahman T, El Zowalaty ME and Rahman M, 2020. Molecular detection of multidrug resistant Salmonella species isolated from broiler farm in Bangladesh. Pathogens 9: 201. https://doi.org/10.3390/pathogens $\underline{9030201}$

Ali AI, Abd El-Mawgoud AM, Dahshan AA, El-Sawah AA and Nasef S, 2019. Escherichia coli in broiler chickens in Egypt, its virulence traits and vaccination as an intervention strategy. Novel Research in Microbiology Journal 3: 415427. https://doi.org/10.21608/NRMJ.2019.44950

Al-Baqir A, Hussein A, Ghanem I and Megahed M, 2019. Characterization of paratyphoid Salmonellae isolated from broiler chickens at Sharkia governorate, Egypt. Zagazig Veterinary Journal 47: 183-192.

Al-Mamun A, Kabir SM, Islam M, Lubna M, Islam SK, Akhter AH and Hossain M, 2017. Molecular identification and characterization of Salmonella species isolated from poultry value chains of Gazipur and Tangail districts of Bangladesh African Journal of Microbiology Research 11: 474-481. https://doi.org/10.21608/ZVJZ.2019.10544.1028

Amer MM, Mekky HM, Amer AM and Fedawy HS, 2018. Antimicrobial resistance genes in pathogenic Escherichia coli isolated from diseased broiler chickens in Egypt and their relationship with the phenotypic resistance characteristics. Veterinary World 11: 1082-1088. https://doi.org/10.14202/vetworld.2018.1082-1088

Atta AH, Shalaby MA and Saifan HY, 2014. Efficacy of commiphoramolmol extract against Clostridium perfringens experimental infection in chickens. World Journal of Pharmacy and Pharmaceutical Sciences 3: 365-380.

Awaad MHH, Elmenawey MA, Afify MA, Zouelfekar SA, Mohamed FF and Demy V, 2019. The impact of high stocking density and Saccharomyces cerevisiae boulardii on productive performance, intestinal microbiota and gut integrity of broiler chickens. International Journal of Veterinary Science 8: 362-370.

Barrow P, Lovell M, Murphy C and Page K, 1999. Salmonella infection in a commercial line of ducks; experimental studies on virulence, intestinal colonization and immune protection. Epidemiology and Infection 123: 121-132. https://dx.doi.org/10.1017/s0950268899002605

Belih S, El-Hadad S, Amen G and Basiony M, 2016. Influence of sodium butyrate on Salmonella infection in broiler chicks. Benha Veterinary Medical Journal 31: 21-32. https://doi.org/10.21608/bvmj.2016.31255

Botlhoko TD, 2009. Performance of Clostridium perfringens challenged broilers inoculated with effective 
microorganisms. MSc Agric. (Animal Science), Faculty of Natural and Agricultural Science, Pretoria University.

Calnek BW, Barnes HJ, Beard CW, McDougald LR and Saif YM, 1997. Diseases of Poultry, 10th Ed, Iowa State University Press, Ames, IA, USA.

Carter GR and Cole JR, 1990. Diagnostic Procedures in Veterinary Bacteriology and Mycology. 5th Ed, Academic Press, New York, USA.

Cooper KK and Songer JG, 2010. Virulence of Clostridium perfringens in an experimental model of poultry necrotic enteritis. Veterinary Microbiology 142: 323-328. https://doi.org/10.1016/j.vetmic.2009.09.065

Dar PS, Wani SA, Wani AH, Hussain I, Maqbool R, Ganaie MY, Kashoo ZA and Qureshi S, 2017. Isolation, identification and molecular characterization of Clostridium perfringens from poultry in Kashmir valley, India. Journal of Entomology and Zoology Studies 5: 409-414.

Das A, Mazumder Y, Dutta BK, Shome BR, Bujarbaruah KM and Kumar A, 2008. Clostridium perfringens type A from broiler chicken with necrotic enteritis. International Journal of Poultry Science 7: 601-609. https://doi.org/10.3923/ijps. 2008.601.609

El-Jakee J, Ata NS, El Shabrawy MA, Abu Elnaga ASM, Hedia RH, Shawky NM and Shawky HM, 2013. Characterization of Clostridium perfringens isolated from poultry. Global Veterinaria 11: 88-94. https://doi.org/10.5829/idosi.gv. 2013.11.1.1138

Ellakany HF, Abd-Elhamid HS, Ibrahim MS, Mostafa NS, Elbestawy AR and Gado AR, 2019. Isolation, serotyping, pathogenicity, and antibiotic sensitivity testing of Escherichia coli from broiler chickens in Egypt. Alexandria Journal of Veterinary Sciences 61: 45-51. https://doi.org/ $\underline{10.5455 / a j v s .10916}$

El-Sawah AA, Dahshan AHM, El-Nahass E and El-Mawgoud AA, 2018. Pathogenicity of Escherichia coli 0157 in commercial broiler chickens. Beni-Suef University Journal of Basic and Applied Sciences 7: 620-625. https://doi.org/ $\underline{10.1016 / j . b j b a s .2018 .07 .005}$

El-Sheikh M, Abdeen E and Ammar A, 2019. Molecular detection of some virulence genes of Salmonella serotypes isolated from poultry in Egypt. Journal of Current Veterinary Research 1: 86-93. https://doi.org/10.21608/JCVR.2019. $\underline{36570}$

Enstrom BE, Fermer C, Lindberg A, Saarinen E, Baverud A and Gunnarsson A, 2003. Molecular typing of isolates of Clostridium perfringens from healthy and diseased poultry. Veterinary Microbiology 94: 225-235. https://doi.org/ 10.1016/s0378-1135(03)00106-8.

Gast RK, Guraya R, Jones DR and Anderson KE, 2013. Colonization of internal organs by Salmonella Enteritidis in experimentally infected laying hens housed in conventional or enriched cages. Poultry Science 92: 468-473. https://doi.org/10.3382/ps/pey541

Hadiujjaman M, Rahman MM, Ahasan MD, Banu MA, Khatun MM and Islam MA, 2016. Isolation and identification of Escherichia coli from apparently healthy chicken of selected areas of Bangladesh. International Journal of Natural and Social Sciences 3: 15-23.

Hafez HM, 2011. Enteric diseases of poultry with special attention to Clostridium perfringens. Pakistan Veterinary Journal 31: 175-184.

Hatakka $M$ and Pakkala $P$, 2003. Incidence of Food Borne Infections in Northern Europe. In: Food Science and Technology. Marcel Dekker, New York, USA, pp: 669-684. https://doi.org/10.1201/9780203912065.pt2

Heba R, Soad A and Mohamed R, 2012. Incidence of E. coli in chickens and ducks in different governorates in Egypt. Conference: First Conference of Animal Health Research Institute Association, pp: 420-426.

Helal S, Khalaf. N, El Menisy A and Lebdah M, 2019. Clostridium perfringens type A causing necrotic enteritis outbreaks among chickens in Egypt. Zagazig Veterinary Journal 47: 398-407. https://doi.org/10.21608/ZVJZ.2019. $\underline{14139.1055}$

Hussein AH, Ghanem IAI, Eid A, Ali MA, Sherwood JS, Li G, Nolan LK and Logue CM, 2013. Molecular and phenotypic characterization of Escherichia coli isolated from broiler chicken flocks in Egypt. Avian Disease 57: 602-611. https://doi.org/10.1637/10503-012513-Reg.1.

Ibrahim RA, Cryer TL, Lafi SQ, Basha EA, Good L and Tarazi YH, 2019. Identification of Escherichia coli from broiler chickens in Jordan, their antimicrobial resistance, gene characterization and the associated risk factors. BMC Veterinary Research 15: 159. https://doi.org/10.1186/ s12917-019-1901-1.

ISO 6579, 2002. Microbiology of food and animal feeding stuffs - Horizontal method for the detection of Salmonella. ISO 6579: 2002 (E) International Standards Organization, Geneva.

Islam MJ, Mahbub-E-Elahi A, Ahmed T and Hasan MK, 2016. Isolation and identification of Salmonella spp. from broiler and their antibiogram study in Sylhet, Bangladesh. Journal of Applied Biology and Biotechnology 4: 046-051. https://doi.org/10.7324/JABB.2016.40308

Jayaweera TS, Ruwandeepika HA, Deekshit VK, Vidanarachchi JK, Kodithuwakku SP, Karunasagar I and Cyril HW, 2020. Isolation and identification of Salmonella spp. from broiler chicken meat in Sri Lanka and their antibiotic resistance. The Journal of Agricultural Sciences - Sri Lanka 15: 395-410. https://doi.org/10.4038/jas.v15i3.9031

Johny AK, Mattson T, Baskaran SA, Amalaradjou MA, Babapoor S, March B, Valipe S, Darre M, Hoagland T, Schreiber D, Khan MI, Donoghue A, Donoghue D and Venkitanarayanana K, 2012. Reduction of compounds transcinnamaldehyde and eugenol. Applied and Environmental Microbiology 78: 2981-2987. https://doi.org/10.1128/AEM. 07643-11

Kaoud HA, El-Babbly MA, El-Iraqi KG and Khalil MM, 2018. Prevalence of Salmonella spp. in some broiler farms in different Egyptian governorates. Journal of Veterinary Medical Research 25: 164-173. https://doi.org/10.21608/ jvmr.2017.43315

Kauffman G, 1974. Kauffman White Scheme. Journal of Acta Pathologica Microbiologica Science 61: 385.

Kok T, Worswich D and Gowans E, 1996. Some serological techniques for microbial and viral infections. In: Practical Medical Microbiology. Lee J, Fraser A, Marmion B and Simmons A (eds), 14th Ed. Edinburgh, Churchill Livingstone, UK.

Komoriya T, Hashimoto A, Shinozaki A, Inoue M and Kohno H, 2007. Study on partial purification of $\alpha$-toxin produced from obligate anaerobe Clostridium perfringens. Report of the Research Institute of Industrial Technology, Nihon University 88: 1-11.

Koneman EW, Auen SD, Dowell VR and Sommers HM, 1988. Color Atlas and Textbook of Diagnostic Microbiology. 2nd Ed. JB Lip Co, New York, USA.

la Mora ZVD, Macías-Rodríguez ME, Arratia-Quijada J, Gonzalez-Torres YS, Nuño K and Villarruel-López A, 2020. Clostridium perfringens as foodborne pathogen in broiler production: Pathophysiology and potential strategies for controlling necrotic enteritis. Animals 10: 1-28. https://doi.org/10.3390/ani10091718

Lee MD and Nolan KL, 2008. Chapter 3: Colibacillosis. In: A Laboratory Manual for the Isolation and Identification of Avian Pathogen. Zavala LD, Swayne DE, Glisson JR, Jack wood MW, Pearson JE and Reed WM (eds). 5th Ed, American Association of Avian Pathologists, USA.

Malmarugan S, Boobalan A and Dorairajan N, 2012. Necrotic enteritis in broiler and layer farms in Tamil Nadu, India International Journal for Agro Veterinary and Medical Sciences 6: 241-249. https://doi.org/10.5455/ijavms.126 
Mehmood K, Bilal RM and Zhang H, 2020. Study on the genotypic and phenotypic resistance of tetracycline antibiotic in Escherichia coli strains isolated from free ranging chickens of Anhui Province, China. Agrobiological Records 2: 63-68. https://doi.org/10.47278/ journal.abr/2020.014

Merati R, Temim S and Mohamed AAA, 2017. Identification and characterization of Clostridium perfringens isolated from necrotic enteritis in broiler chickens in Tiaret, Western Algeria. Kafkas Üniversitesi Veteriner Fakültesi Dergisi 23: 595-601.

Moawad AA, Hotzel H, Awad O, Tomaso H, Neubauer H, Hafez HM and El-Adawy H, 2017.Occurrence of Salmonella enterica and Escherichia coli in raw chicken and beef meat in northern Egypt and dissemination of their antibiotic resistance markers. Gut Pathogens 9: 57. https://doi.org/ 10.1186/s13099-017-0206-9

Mridha D, Uddin MN, Alam B, Akhter AH, Islam SK, Islam MS, Khan MSR and Kabir SM, 2020. Identification and characterization of Salmonella spp. from samples of broiler farms in selected districts of Bangladesh. Veterinary World 13: 275-283. https://doi.org/10.9775/kvfd.2017.17431

Muna EA, Salih MH, Zakia AM, Halima MO, Abeer AM, Ameera MM, Ali HO and Idris SB, 2016. Pathology of broiler chicks naturally infected with Salmonella enteritidis ( $S$. enteritidis) and Salmonella typhimurium (S. typhimurium) during an outbreak in Sudan. Journal of Scientific Research and Reports 10: 1-8. https://doi.org/ 10.9734/jsrr/2016/23431

Osman KM, Soliman YA, Amin ZMS and Aly MAK, 2012. Prevalence of Clostridium perfringens type A isolates in commercial broiler chickens and parent broiler breeder hens in Egypt. Revue Scientifique et Technique (International Office of Epizootics) 31: 931-941. https://doi.org/10.20506/ $\underline{\text { rst.31.3.2169 }}$

Palliyeguru MW, Rose SP and Mackenzie AM, 2010. Effect of dietary protein concentrates on the incidence of $\mathrm{NE}$ and growth performance of broiler chickens. Journal of Poultry Science 89: 34-43.

Park JY, Kim S, Oh JY, Kim HR, Jang I, Lee HSand Ki YK, 2015. Characterization of Clostridium perfringens isolates obtained from 2010 to 2012 from chickens with necrotic enteritis in Korea. Poultry Science 94: 1158-1164. https://doi.org/10.3382/ps/pev037

Popoff MY, 2001. Antigenic formulas of the Salmonella servers, WHO Collaborating Center for Reference and Research on Salmonella, Paris. 8th Ed. Porter RE Jr, 1998. Bacterial enteritides of poultry. Poultry Science 77: 1159-1165. https://doi.org/10.1093/ps/77.8.1159

Rahman M, Samad M, Rahman MJ and Kabir S, 2004. Bacteriopathological studies on salmonellosis, colibacillosis and pasteurellosis in natural and experimental infections in chickens. Bangladesh Journal of Veterinary Medicine 2: 18. https://doi.org/10.3329/bjvm.v2i1.1926

Reynolds DL, 2003. Multicausal enteric diseases. In: Diseases of poultry (ed. YM Saif), Iowa State University Press, Ames, IA, USA, pp: 1169-1171.

Ronco T, Stegger M., Heidemann R, Sekse C, Bang A, Pohjanvirta T, Lilje B, Ulrike L, Skytt P and Pedersen K, 2017. Spread of avian pathogenic Escherichia coli ST117 O78:H4 in Nordic broiler production. BMC Genomics 18: 13. https://doi.org/10.1186/s12864-016-

Saha AK, Sufian MA, Hossain MI and Hossain MM, 2012. Salmonellosis in layer chickens: pathological features and isolation of bacteria from ovaries and inner content of laid eggs. Journal of Bangladesh Agriculture University, 10: 6167. https://doi.org/10.3329/jbau.v10i1.12095

Shah SA, Mir MS, Wani BM, Kamil SA, Goswami P, Amin U, Shafi M, Rather MA, Beigh AB, 2019. Pathological studies on avian pathogenic Escherichia coli infection in broilers. Pharma Innovation 8: 68-73.

Sarba E, Kelbesa K, Bayu M, Gebremedhin E, Borena B and Teshale A, 2019. Identification and antimicrobial susceptibility profile of Escherichia coli isolated from backyard chicken in and around ambo, Central Ethiopia. BMC Veterinary Research 15: 85. https://doi.org/10.1186/ $\underline{\text { s12917-019-1830-Z }}$

Sarkar M, Ray JP, Mukhopadhayay SK, Niyogi D and Ganguly S, 2013. Study on Clostridium perfringens type A infection in broilers of West Bengal, India. IIOAB Journal 4: 1-3.

Schlundt J, 2002. New directions in foodborne disease prevention. International Journal of Food Microbiology 78: 3-17.

Sedeik ME, El-shall NA, AAM Elfeky, Abd El-Hack ME, Hussein EOS, Alowaimer AN and Swelum AA, 2019. Isolation, conventional and molecular characterization of Salmonella spp. From newly hatched broiler chicks. AMB Express 9: 136. https://doi.org/10.1186/s13568-019-0821-6

Shoaib M, Dasti JI, Shah MAA, Zafar MA, Hasan MU, Riaz A, Rehman SU and Khan MA, 2017. Salmonellosis in poultry, new prospects of an old disease: a review. Pakistan Journal of Science 69: 361-368.

Slaoui M and Fiette L, 2011. Histopathology procedures: from tissue sampling to histopathological evaluation. Methods in Molecular Biology 691: 69-82. https://doi.org/10.1007/9781-60761-849-2_4

Soliman S, Seida AA, El-Fakar SZ, Youssef YI and El-Jakee J, 2018. Salmonella infection in broiler flocks in Egypt. Bioscience Research 15: 1925-1930.

Su YC, Yu CY, Lin JL, Lai JM, Chen SW, Tu PC and Chu C, 2011. Emergence of Salmonella Enterica sero-var Potsdam as a major serovar in waterfowl hatcheries and chicken eggs. Avian Disease 55: 217-222. https://doi.org/10.1637/ 9420060910-Reg.1

Surra G, Dereje T and Chaluma N, 2018. Isolation and identification of Escherichia coli, Salmonella and Pasteurella from holding grounds of live-bird markets at Addis Ababa, Ethiopia. African Journal of Microbiology Research 12: 754-760.

Uzal FA, Freedman JC, Shrestha A, Theoret JR, Garcia J, Awad MM, Adam SV, Moore RJ, Rood JI and McClane B, 2014 Towards an understanding of the role of Clostridium perfringens toxins in human and animal disease. Future Microbiology 9: 361-377. https://doi.org/10.2217/fmb.13.168

van Asten AJAM, van der Wiel CW, Nikolaou G, Houwers DJ and Grone A, 2009. A multiplex PCR for toxin typing of Clostridium perfringens. Veterinary Microbiology 136: 411412. https://doi.org/10.1016/j.vetmic.2008.11.024.

Wang J, Li J, Liu F, Cheng Y and Su J, 2020. Characterization of Salmonella enterica isolates from diseased poultry in northern China between 2014 and 2018. Pathogens 9: 95. https://doi.org/10.3390/pathogens 9020095

Williams RB, 2005. Intercurrent coccidiosis and necrotic enteritis of chickens: Rational, integrated disease management by maintenance of gut integrity. Avian Pathology 34: 159-180. https://doi.org/10.1080/03079450500112195

Williams RB, Marshall RN, La Ragione RM and Catchpole J, 2003. A new method for the experimental production of necrotic enteritis and its use for studies on the relationships between necrotic enteritis, coccidiosis and anticoccidial vaccination of chickens. Parasitological Research 90: 19-26. https://doi.org/10.1007/s00436-002-0803-4

Yasmin S, Nawaz M, Anjum AA, Ashraf K, Basra MAR, Mehmood A, Khan I and Malik F, 2020. Phytochemical analysis and in vitro activity of essential oils of selected plants against Salmonella enteritidis and Salmonella gallinarum of poultry origin. Pakistan Veterinary Journal_40: 139-144. https://doi.org/10.29261/pakvetj/2019.110 